This is a post-print (after review) of the following article:

Yann Bethuel and Karl Gademann

Stereoselective Total Synthesis of (-)-Galantinic Acid

Synlett 2006, 1580-1582.

DOI: $10.1055 / \mathrm{s}-2006-941602$

(C) Georg Thieme Verlag Stuttgart · New York

The official version can be retrieved from

http://www.thieme-connect.com

This post-print has been deposited at

http://infoscience.epfl.ch 


\section{Stereoselective Total Synthesis of (-)-Galantinic Acid}

Yann Bethuel and Karl Gademann*

Laboratorium für Organische Chemie, ETH Zürich, CH-8093 Zürich

Fax: ++41446321328

E-mail: gademann@org.chem.ethz.ch

Received: The date will be inserted once the manuscript is accepted.

Abstract: A concise, practical and stereoselective total synthesis of galantinic acid, constituent of the peptide antibiotic galantin, is reported. The title compound is obtained in six steps via Heathcock-Claisen condensation, Evans reduction and deprotection in $30 \%$ overall yield from protected serine. The route described herein thus constitutes the shortest and most efficient procedure for the preparation of the title compound disclosed so far.

Key words: Amino acids, antibiotics, natural products, peptides, polyketides.

Galantinic acid (1) was first isolated as a degradation product of the peptide antibiotic galantin I (3), obtained from fermentation of Bacillus pulvifaciens. ${ }^{1}$ The originally proposed structure 2 of galantinic acid ${ }^{1}$ was later shown to be incorrect by total synthesis and was revised to $1 .^{2}$ It is interesting to note that although many $\beta$ hydroxy- $\gamma$-amino acids are constituents of natural products with potent biological activity such as didemnin ${ }^{3 \mathrm{a}}$ or dolastatin $10^{3 \mathrm{~b}}$, the corresponding $\varepsilon$-amino acids resulting from an additional insertion of an acetate unit are much less frequently observed. ${ }^{4}$ Galantinic acid (1) is considered an interesting target for synthesis, due to its biological activity and the highly functionalized $\mathrm{C}_{7}$ framework. Moreover, 1 can be considered of interesting biosynthetic origin, as its bioproduction likely involves non-ribosomal peptide synthetase and polyketide synthase enzymes. Therefore, several syntheses of 1 were reported so far. ${ }^{2,5}$ All these routes, however, display limitations such as length (12-18 steps) ${ }^{6}$, impracticability or use of expensive reagents. We report in this letter a simple, short and efficient route to (-)-galantinic acid (1), which favorably compares to earlier approaches.

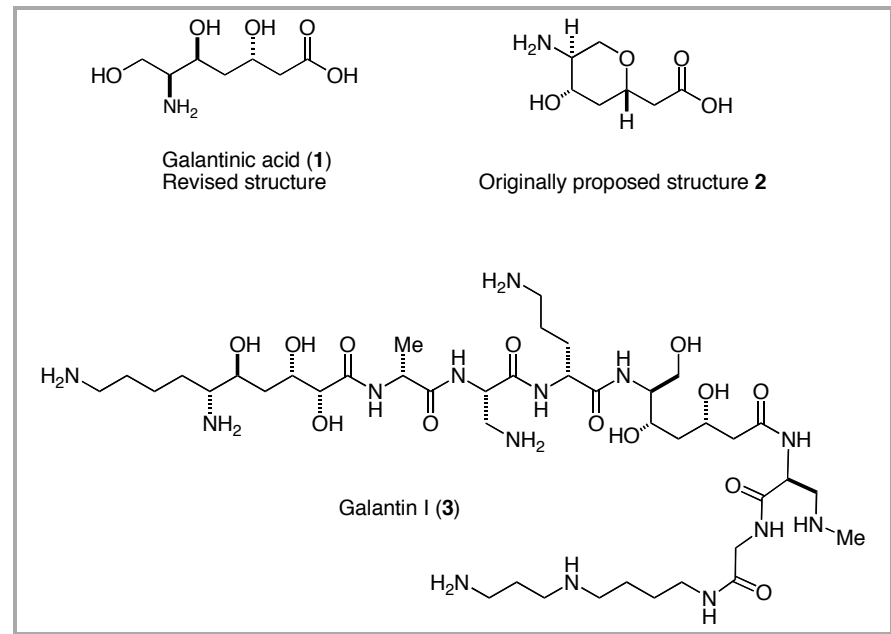

The synthesis started from the $\beta$-hydroxy- $\gamma$-amino acid $\mathbf{5}$, which is readily prepared on a $20 \mathrm{~g}$ scale starting from protected serine $\mathbf{4}$, which is commercially available
(Scheme 1). ${ }^{7}$ A Claisen condensation using the procedure of Heathcock ${ }^{8}$ employing 6 equivalents of lithiated tert-butyl acetate gave the hydroxyketoester 6 in $75 \%$ yield. ${ }^{9}$ This transformation is remarkable, as the dianion resulting from deprotonation of the acidic $\mathrm{NH}$ and $\mathrm{OH}$ protons is soluble and reactive towards the enolate. In situ trapping of the resulting keto ester allowed for a high yielding access to this intermediate $\mathbf{6}$ in only three steps starting from protected serine 4 . As noted earlier by Heathcock, ${ }^{8}$ we found that the use of an excess of the enolate lead to significantly higher yields. The keto ester $\mathbf{6}$ is then reduced by directed hydride delivery following the method of Evans and coworkers ${ }^{10}$ to give the anti 3,5-diol 7 in high stereoselectivity (>95:5). ${ }^{1}$ The carbamate protected amine adjacent to the directing $\mathrm{OH}$-group is fully compatible with the reaction conditions and did not deter rate nor selectivity. The diol 7 was then deprotected first by hydrogenolysis, where the addition of acetic acid was found to be crucial. Without this additive, the OBn group was found to be unreactive. The conditions for the cleavage of the tert-butyl ester also needed to be carefully evaluated, as exposure to mineral acids such as $\mathrm{HCl}$ or prolonged reaction times resulted in significant amounts of the galantinic acid $\delta$-lactone. Short treatment with trifluoroacetic acid gave, after purification on dowex ion exchange resin, a sample of ()-galantinic acid (1), of which the physical data was found in full agreement with the published values. ${ }^{2 b}$

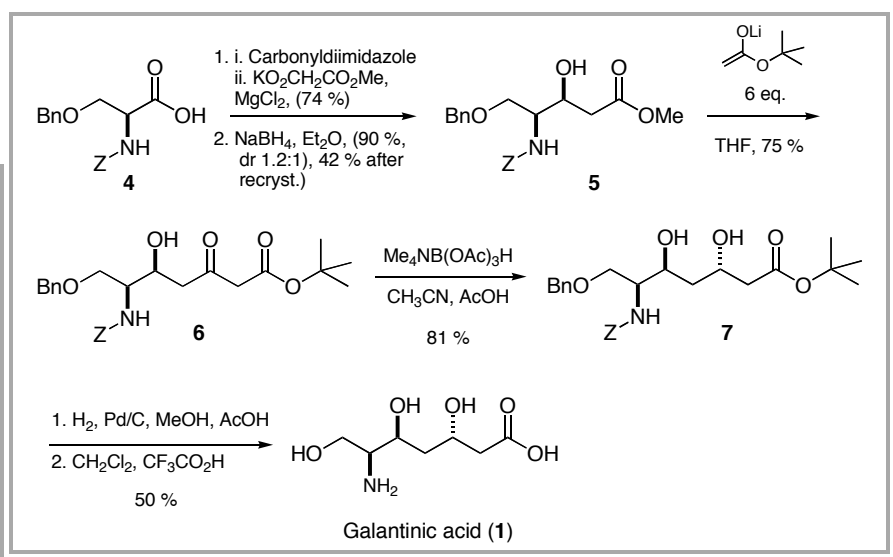

Scheme 1. Synthesis of galantinic acid (1).

In conclusion, we report a short, stereoselective total synthesis of (-)-galantinic acid (1), constituent of the peptide antibiotic galantin (3). Key features of our synthesis include (1) a Claisen condensation according to Heathcock, (2) directed hydride delivery and (3) a short access to a complex aminohydroxy acid in just six steps 
starting from commercially available, protected serine 4 . The route disclosed in this letter thus favorably associate both regarding number of steps (i.e. 6 vs. 12-18) and overall yield to previously published procedures for the synthesis of galantinic acid. ${ }^{6,12}$ This procedure exemplifies that the homologation/reduction strategy provides a rapid access to certain polyacetate structures. Moreover, the preparation of galantin analogs allowing for structure/activity relationships as well as the use of this interesting building block for e.g. protease inhibitors can now be envisioned.

\section{Acknowledgment}

$K$. G. thanks Prof. Dr. Erick M. Carreira for generous financial support in the context of his habilitation, as well as the Schweizerischer Nationalfonds zur Förderung der wissenschaftlichen Forschung (Grant Nr. 200021-101601/1, PhD fellowship Y.B.).

\section{References and notes}

(1) Shoji, J.; Sakajaki, R.; Wakisaka, Y.; Koizumi, K.; Mayama, M.; Matsurra, S. J. J. Antibiot. 1975, 28, 122-125.

(2) a) Sakai, N.; Ohfune, Y. Tetrahedron Lett. 1990, 29, 41514154. b) Sakai, N.; Ohfune, Y. J. Am. Chem. Soc. 1992, 114, 998-1010.

(3) For example, the didemnins Rinehart, K. L.; Gloer, J. B.; Hughes, R. G.; Renis, H. E.; McGovern, J. P.; Swynenberg, E. B.; Stringfellow, D. A.; Kuentzel, S. L.; Li, L. H. Science 1981, 211, 933-935. Dolastatin 10: Pettit, G. R.; Kamano, Y.; Herald, C. L.; Tuinman, A. A.; Boettner, F. E.; Kizu, H.; Schmidt, J. M.; Baczynskyj, L.; Tomer, K. B.; Bontems, R. J. J. Am. Chem. Soc. 1987, 109, 6883-6885.

(4) See, for example: Kondo, S. I.; Akita, E.; Sezaki, M.; J. Antibiot. 1966, 19, 137-140.

(5) a) Ikota, N. Heterocycles 1991, 31, 521-528. b) Kumar, J. S. R.; Datta, A. Tetrahedron Lett. 1999, 40, 1381-1384. c) Kiyooka, S.; Goh, K.; Nakamura, Y.; Takesue, H.; Hena, M. A. Tetrahedron Lett. 2000, 41, 6599-6603. d) Moreau, X.; Campagne, J. -M. Tetrahedron Lett. 2001, 42, 4467 4469. e) Raghavan, S.; Reddy, S. R. J. Org. Chem. 2003, 68, 5754-5757. f) Kumar Pandey, S.; Kandula, S. V.; Kumar, P. Tetrahedron Lett. 2004, 45, 5877-5879.

(6) For example: Ref [2a], 13 steps from protected serine; ref [5f], 12 steps from propanediol; ref [5e] 18 steps from a propargylic epoxide. Moreau and Campagne obtained a semi-protected ester derivative of $\mathbf{1}$ in 6 steps overall (ref [5d]).

(7) Gademann, K.; Bethuel, Y. Angew. Chem. 2004, 116, 3389 -3391. Angew. Chem. Int. Ed. 2004, 43, 3327-3329. There are numerous methods for the stereoselective preparation of $\beta$-hydroxy- $\gamma$-amino acids, so-called statins. Reviews: Javier Sardina, F.; Rapoport, H. Chem. Rev. 1996, 96, 1825-1872. Vera, M. D.; Joullié, M. M. Med. Res. Rev. 2002, 22, 102-145. See also: Brenner, M.; Seebach, D. Helv. Chim. Acta 2001, 84, 1181-1189. Jouin, P.; Castro, B.; Nisato, D. J. Chem. Soc. Perkin Trans. 1 1987, 11771182.

(8) Hubbs, J. L.; Heathcock, C. H. J. Am. Chem. Soc. 2003, $125,12836-12843$. Earlier works used reduced amounts of enolate, see, for example: Lynch, J. E.; Volante, R. P.; Wattley, R. V.; Shinkai, I. Tetrahedron Lett. 1987, 28, 13851388.

(9) Preparation and selected data for 6 :

BuLi (1.6 M solution in hexane, $2.90 \mathrm{~mL}, 4.60 \mathrm{mmol}, 6.00$ equiv) was added dropwise to a solution of $\mathrm{iPr}_{2} \mathrm{NH}$ (691 $\mu \mathrm{L}, 4.90 \mathrm{mmol}, 6.40$ equiv $)$ in dry $\mathrm{THF}(2.00 \mathrm{~mL})$ at $0{ }^{\circ} \mathrm{C}$. The reaction mixture was stirred at this temperature for 10 min and then cooled to $-78{ }^{\circ} \mathrm{C}$. AcOtBu $(623 \mu \mathrm{L}, 4.60$ mmol, 6.00 equiv) was added dropwise and the reaction mixture was stirred at this temperature for $1 \mathrm{~h}$. The resulting enolate was cannulated into a solution of $(3 S, 4 S)-5$ benzyloxy-4-benzyloxycarbonylamino-3-(tert-butyldimethyl-silanyloxy)-pentanoic acid methyl ester $(\mathbf{5}, 0.300$ $\mathrm{g}, 775 \mu \mathrm{mol}, 1.00$ equiv) in dry THF $(2.00 \mathrm{~mL})$ at $0^{\circ} \mathrm{C}$. The reaction mixture was stirred $1 \mathrm{~h}$ at $0{ }^{\circ} \mathrm{C}, 30 \mathrm{~min}$ at $\mathrm{RT}$ and then quenched with saturated aqueous $\mathrm{NH}_{4} \mathrm{Cl}$ solution and the THF was evaporated. A mixture of $\mathrm{NH}_{4} \mathrm{Cl} / \mathrm{H}_{2} \mathrm{O}(1: 1)$ was added and the solution was $3 \mathrm{x}$ extracted with EtOAc. The combined organic layers were washed with saturated aqueous $\mathrm{NH}_{4} \mathrm{Cl}$ solution, dried over $\mathrm{Na}_{2} \mathrm{SO}_{4}$, filtered and evaporated under reduced pressure. Purification by flash chromatography (EtOAc/hexane 1:7) gave $6(274 \mathrm{mg}, 581$ $\mu \mathrm{mol}, 75 \%$ yield) as a colorless oil. $R_{\mathrm{f}}=0.34$ (EtOAc/hexane 4:6). Optical rotation $[\alpha]_{\mathrm{D}}^{25}$ (c 5.22, $\left.\mathrm{CHCl}_{3}\right)=+0.2^{\circ} .{ }^{1} \mathrm{H}-\mathrm{NMR}\left(300 \mathrm{MHz} \mathrm{CDCl}_{3}\right) 1.45(\mathrm{~s}, 9 \mathrm{H})$, $2.65\left(\mathrm{dd}, 1 \mathrm{H}, J_{1}=4.0 \mathrm{~Hz}, J_{2}=17.7 \mathrm{~Hz}\right), 2.79\left(\mathrm{dd}, 1 \mathrm{H}, J_{1}=\right.$ $\left.8.7 \mathrm{~Hz}, J_{2}=17.4 \mathrm{~Hz}\right), 3.33\left(\mathrm{dd}, 1 \mathrm{H}, J_{1}=2.5 \mathrm{~Hz}, J_{2}=10.3\right.$ $\mathrm{Hz}), 3.35$ (s, 2H), 3.64 (m, 2H), 3.76-3.86 (m, 1H), 4.40$4.48(\mathrm{~m}, 1 \mathrm{H}), 4.51(\mathrm{~s}, 2 \mathrm{H}), 5.11(\mathrm{~s}, 2 \mathrm{H}), 5.39(\mathrm{~d}, 1 \mathrm{H}, J=$ $9.3 \mathrm{~Hz}), 7.28-7.36(\mathrm{~m}, 10 \mathrm{H}) .{ }^{13} \mathrm{C}-\mathrm{NMR}\left(75 \mathrm{MHz}, \mathrm{CDCl}_{3}\right)$ 28.0, 28.1, 46.6, 51.1, 53.3, 66.9, 67.3, 67.4, 71.0, 82.2, $127.5,127.8,128.3,128.6,136.2,137.4,156.3,165.9$, 203.0. IR 3606-3187w, 2977w, 1744m, 1712s. MS 494.2 $\left(17,[M+\mathrm{Na}]^{+}\right), 394.2\left(81,\left[\mathrm{M}-\mathrm{CO}_{2} \mathrm{tBu}+\mathrm{Na}\right]^{+}\right)$. HRMS (MALDI) calcd. for $\mathrm{C}_{26} \mathrm{H}_{33} \mathrm{NO}_{7} \mathrm{Na}[\mathrm{M}+\mathrm{Na}$ ], 494.2149; found, 494.2141.

(10) Evans, D. A.; Chapman, K. T.; Carreira, E. M. J. Am. Chem. Soc. 1988, 110, 3560-3578.

(11) Preparation and selected data for 7 : A solution of 6 (135 mg, $0.290 \mathrm{mmol}, 1.00$ equiv) in $\mathrm{CH}_{3} \mathrm{CN}(1.50 \mathrm{~mL})$ was cooled to $-35^{\circ} \mathrm{C}$ and $\mathrm{Me}_{4} \mathrm{~N}(\mathrm{OAc})_{3} \mathrm{BH}(534 \mathrm{mg}, 2.03 \mathrm{mmol}, 7.00$ equiv) dissolved in $\mathrm{CH}_{3} \mathrm{CN} / \mathrm{AcOH}(1.00 \mathrm{~mL} / 1.00 \mathrm{~mL})$ was added. The reaction mixture was stirred at this temperature for 62 hours. It was then warmed to $0{ }^{\circ} \mathrm{C}$ and a saturated solution of Na-K-tartrate was added. The solution was stirred at this temperature for $4 \mathrm{~h}$. The phases were separated and the aqueous phase $3 \mathrm{x}$ extracted with EtOAc. The combined organic layers were washed with brine, dried over $\mathrm{Na}_{2} \mathrm{SO}_{4}$, filtered and evaporated under reduced pressure. FC (hexane/EtOAc 6:4) gave 7 (111 $\mathrm{mg}, 0.235 \mathrm{mmol}, 81 \%)$ as a colorless oil. $R_{\mathrm{f}}=0.38(\mathrm{EtOAc} /$ hexane $1: 1)$. Optical rotation $[\alpha]_{\mathrm{D}}{ }^{25}(\mathrm{c}=0.86, \mathrm{CHCl} 3)=+0.35^{\circ} .{ }^{1} \mathrm{H}-\mathrm{NMR}\left(\mathrm{CDCl}_{3}\right.$, $300 \mathrm{MHz}) 1.46(\mathrm{~s}, 9 \mathrm{H}), 1.50-1.60(\mathrm{~m}, 1 \mathrm{H}), 1.64-1.78(\mathrm{~m}$, $1 \mathrm{H}), 2.39(\mathrm{~d}, 2 \mathrm{H}, J=5.6 \mathrm{~Hz}), 3.43(\mathrm{~m}, 1 \mathrm{H}), 3.58(\mathrm{~d}, 1 \mathrm{H}, J$ $=3.73 \mathrm{~Hz}), 3.67(\mathrm{~d}, 2 \mathrm{H}, J=4.1 \mathrm{~Hz}), 3.72(\mathrm{~m}, 1 \mathrm{H}), 4.18$ $4.30(\mathrm{~m}, 2 \mathrm{H}), 4.50(\mathrm{~s}, 2 \mathrm{H}), 5.10(\mathrm{~s}, 2 \mathrm{H}), 5.51(\mathrm{~d}, 1 \mathrm{H}, J=$ $9.3 \mathrm{~Hz}), 7.20-7.40(\mathrm{~m}, 10 \mathrm{H}) .{ }^{13} \mathrm{C}-\mathrm{NMR}\left(\mathrm{CDCl}_{3}, 75 \mathrm{MHz}\right)$ 28.2, 39.7, 42.3, 54.2, 65.4, 66.8, 68.8, 72.2, 73.6, 81.3, 127.6, 127.8, 127.8, 127.9, 128.0, 128.4, 136.3, 137.3, $156.4,172.2$. IR $3636-3117 w, 2977 w, 1715 s$. MS 496.2 $\left(41,[\mathrm{M}+\mathrm{Na}]^{+}\right), 440.2\left(100,\left[\mathrm{M}-2 \mathrm{H}_{2} \mathrm{O}+\mathrm{H}\right]^{+}\right) . \mathrm{HRMS}$ (MALDI) calcd. for $\mathrm{C}_{26} \mathrm{H}_{35} \mathrm{NO}_{7} \mathrm{Na}(\mathrm{M}+\mathrm{Na})^{+}: 496.2306$, found: 496.2299 .

(12) Ref. 5d describes the synthesis of protected galantinic butyl ester in 8 steps from a commercially available serine derivative. We found that the deprotection of this butyl ester under basic conditions results in partial decomposition, epimerization, lactone formation and dehydration. The use of an acid labile protecting group such as in the route presented in this letter thus greatly facilitates deprotection and thus the preparation of target galantinic acid. 